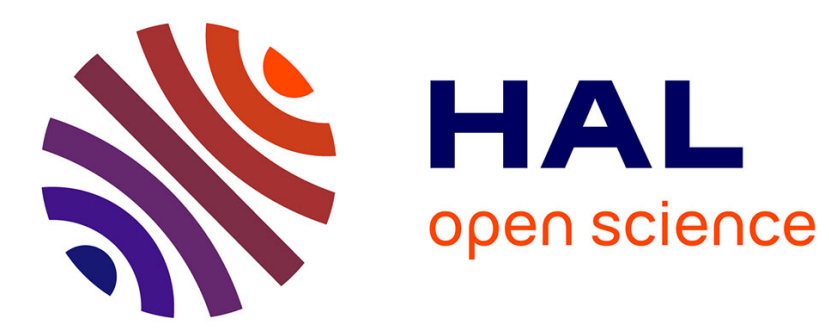

\title{
Hydroxyethyl Starch vs Saline for Volume Expansion After Abdominal Surgery-Reply
}

\author{
Emmanuel Futier, Bruno Pereira, Samir Jaber
}

\section{To cite this version:}

Emmanuel Futier, Bruno Pereira, Samir Jaber. Hydroxyethyl Starch vs Saline for Volume Expansion After Abdominal Surgery-Reply. JAMA Cardiology, 2020, 324 (2), pp.200. 10.1001/jama.2020.6983 . hal-02899899

\section{HAL Id: hal-02899899 \\ https://hal.science/hal-02899899}

Submitted on 25 Jul 2020

HAL is a multi-disciplinary open access archive for the deposit and dissemination of scientific research documents, whether they are published or not. The documents may come from teaching and research institutions in France or abroad, or from public or private research centers.
L'archive ouverte pluridisciplinaire HAL, est destinée au dépôt et à la diffusion de documents scientifiques de niveau recherche, publiés ou non, émanant des établissements d'enseignement et de recherche français ou étrangers, des laboratoires publics ou privés. 


\section{Hydroxyethyl Starch vs Saline for Volume Expansion After Abdominal Surgery}

Emmanuel Futier, MD, PhD

Bruno Pereira, PhD

Samir Jaber, MD, PhD
In Reply Dr Mascha argues that the between-group difference in KDIGO stages of AKI in the trial ${ }^{1}$ might have resulted from incorrect analysis of ordinal variables. However, rather than a comparison of each KDIGO stage with all other stages of severity, the absence of kidney dysfunction (stage 0 ) was used as a reference. The omnibus $P$ value from the $\chi^{2}$ test is .17 . The same result is obtained with a multinomial (polytomous) logistic regression, which allows comparison of groups overall and vs a reference modality, taking into account the ordinal nature of the variable. $P$ values for each comparison are unchanged, irrespective of whether $2 \times 2 \chi^{2}$ comparisons (without correction for type I error, as indicated in the statistical analysis section) or multinomial logistic regression is used.
Dr Markow raises concern about the sex distribution in the study population and its connection to outcome. We agree that use of the acute kidney injury index ${ }^{1}$ for patient risk stratification in the trial may have contributed to the sex ratio imbalance, as well as overrepresentation of other components of the risk index (eg, hypertension) compared with the general surgical population. Data from the American College of SurgeonsNational Surgical Quality Improvement Program ${ }^{2}$ showed that male sex doubles the risk of AKI after general surgery. However, in the FLASH trial, male sex was not associated with the primary outcome (odds ratio, 1.42; 95\% CI, 0.87-2.31).

We agree with Dr Xue and colleagues that larger amounts of intravenous fluids resulting in positive cumulative fluid balance may artificially lower serum creatinine and influence the diagnosis of AKI. No adjustment for the effect of fluid balance was made given that our assessment of fluid balance was a post hoc analysis and the findings were only hypothesis generating.

Xue and colleagues are also concerned about missing information on preoperative anemia and hypoalbuminemia. We did not collect serum albumin data, but the 2 treatment groups did not differ with regard to hemoglobin levels at baseline (mean, 13.1 [SD, 1.9] g/L in the HES group and 13.3 [SD, 1.8] g/L in the saline group; $P=.30$ ).

The possible influence of intraoperative hypotension on outcomes is important to consider. ${ }^{3}$ The recommendation was made to maintain mean arterial pressure of $60 \mathrm{~mm} \mathrm{Hg}$ or higher during surgery, but possible imbalance between groups cannot be excluded. Nevertheless, no between-group differences were noted in mean arterial pressure at the end of surgery or in mean doses of intraoperative vasopressor.

Xue and colleagues question the duration of monitoring of kidney function in the trial. We presented data on kidney function up to 28 days in the article. Nevertheless, we concur that an increased need for renal replacement therapy has been reported up to 90 days after HES administration.

Drs De Backer and Michiels are concerned about the administration of fluids other than study fluids in the trial. The protocol restricted the use of study fluids to intravascular volume expansion to a maximum daily dose of $30 \mathrm{~mL} / \mathrm{kg}$, beyond which open-label fluids were given for fluid therapy. Although the use of study fluids as a single therapy (including as maintenance intravenous fluids) might have enhanced the trial design, this methodology could be criticized from a clinical perspective. ${ }^{4}$

De Backer and Michiels point out the possible confounding effect of the co-administration of HES in a significant amount in the 2 groups, thus minimizing differences in outcomes. In practice, the co-administration of HES during the study period was noted in 2 patients in the HES group and in 4 patients in the saline group $(P=.17)$, without a difference in the dose administered (median, 300 [interquartile range, $100-500$ ] $\mathrm{mL}$ in the HES group and 500 [interquartile range, 500-750] $\mathrm{mL}$ in the saline group; $P=.45$ ). 
Emmanuel Futier, MD, PhD

Bruno Pereira, PhD

Samir Jaber, MD, PhD

Author Affiliations: Hôpital Estaing, Centre Hospitalier Universitaire (CHU) Clermont-Ferrand, Clermont-Ferrand, France (Futier); Direction de la Recherche Clinique (DRCI), Centre Hospitalier Universitaire (CHU) Clermont-Ferrand, Clermont-Ferrand, France (Pereira); Hôpital Saint-Eloi, Centre Hospitalier Universitaire (CHU) Montpellier, Montpellier, France (Jaber).

Corresponding Author: Emmanuel Futier, MD, PhD, Département Anesthésie Réanimation, Hôpital Estaing, One Place Lucie Aubrac, 63003 Clermont-Ferrand, France (efutier@chu-clermontferrand.fr).

Conflict of Interest Disclosures: Dr Futier reported receiving grants from the French Healthcare Society (Agence Nationale de Sécurité du Médicament et des Produits de Santé) and the Société Francaise d'Anesthésie Réanimation (SFAR) and personal fees from Drager Medical, GE Healthcare, Edwards Lifesciences, Orion Pharma, Baxter, Fresenius Kabi, and Fisher \& Paykel. Dr Jaber reported receiving personal fees from Drager, Fisher \& Paykel, Medtronic, Fresenius-Xenios, and Baxter. No other disclosures were reported.

1. Futier $E$, Garot M, Godet T, et al; FLASH Trial Group. Effect of hydroxyethyl starch vs saline for volume replacement therapy on death or postoperative complications among high-risk patients undergoing major abdominal surgery: the FLASH randomized clinical trial. JAMA. 2020;323(3):225-236. doi:10.1001/ jama.2019.20833

2. Kheterpal S, Tremper KK, Heung M, et al. Development and validation of an acute kidney injury risk index for patients undergoing general surgery: results from a national data set. Anesthesiology. 2009;110(3):505-515. doi:10.1097/ ALN.Ob013e3181979440

3. Futier E, Lefrant JY, Guinot PG, et al; INPRESS Study Group. Effect of individualized vs standard blood pressure management strategies on postoperative organ dysfunction among high-risk patients undergoing major surgery: a randomized clinical trial. JAMA. 2017;318(14):1346-1357. doi:10.1001/ jama.2017.14172

4. Moritz ML, Ayus JC. Maintenance intravenous fluids in acutely ill patients. N Engl J Med. 2015;373(14):1350-1360. doi:10.1056/NEJMra1412877 